\title{
Coaching Leadership and Time: A Finnish Perspective
}

\author{
Seppo Pulkkinen, Tapio Juhani Lahtero, Pekka Kanervio, Mika Risku \\ University of Jyväskylä, Jyväskylä, Finland
}

\begin{abstract}
In this article, we will examine coaching leadership in connection to pedagogical leadership, the role of time in it, and the influence of both coaching leadership and time in leading educational organizations. Special interest will be given to the opportunities coaching leadership offers. Coaching has changed Finnish leadership significantly. Through coaching, people have started to have to give up their old leadership practices. The new practices are constructed on leadership based on the principles of coaching. Coaching leadership in part makes use of shared leadership whose opportunities have improved leadership further. As with other approaches of leadership, time seems to remain as an essential challenge for successful leadership also concerning coaching leadership.
\end{abstract}

Keywords: coaching leadership, time, sports world, school world

\section{Value of Article}

This article examines coaching leadership in connection to pedagogical leadership in Finland. In doing so, it fills the void of having research information on coaching leadership in the Finnish context. The article is mainly targeted for coaches, principals, and researchers.

\section{Introduction}

In this article, we will examine the core contents of coaching leadership in connection to pedagogical leadership, the role of time in it, and the influence of both coaching leadership and time to practical work in leading educational organizations. Special interest will be given to the opportunities coaching leadership offers.

In the world of sports, one can locate the following two antipodean approaches of coaching: the older managerial coaching of giving orders and the current participating one. When referring to coaching leadership, the focus is on the latter one. That approach requires leaders to be able to engage themselves in humane encounters, to understand the holistic nature of people's contexts and personalities, to have sufficient communication skills, and to enact ethically acceptable and sustainable actions (Kuusilehto-Awale \& Pulkkinen, 2013).

In Finland, coaching leadership was established as a term first during the last decade and then confined to the sports world (Carlsson \& Forssell, 2008). Concerning general leadership discussions, the term has had stronger and wider use only during the last five years (Harmaja \& Hellbom, 2007). Literature based on the broader scope of coaching leadership is not that prolific in Finland. In fact, the concept of coaching leadership

Seppo Pulkkinen, Ph.D., researcher, Institute of Educational Leadership, University of Jyväskylä.

Tapio Juhani Lahtero, Ph.D., superintendent, Institute of Educational Leadership, University of Jyväskylä.

Pekka Kanervio, Ph.D., researcher, Institute of Educational Leadership, University of Jyväskylä.

Mika Risku, M.A., director, Institute of Educational Leadership, University of Jyväskylä. 
is still somewhat indecisive to Finns. For example, it may be used also to refer to managerial coaching (Kuusilehto-Awale \& Pulkkinen, 2013). In the present article, coaching leadership is used solely to refer to the participating approach of coaching.

This article is the result of the writers' dialogue on the characteristics of coaching leadership. The dialogue has a strong connection to the theory of broad pedagogical leadership which, for the purpose of the present article, can be summarized as a leadership approach emphasizing leading both individual and organizational learning to meet the challenges of changing contexts (Alava, Halttunen, \& Risku, 2012). For the enactment of the broad pedagogical leadership, dialogue and mentoring, in the same way as for coaching leadership, can be considered as essential leadership tools. In fact, one could claim that coaching leadership is embedded in the broad pedagogical leadership theory. Concerning the sports world, Pulkkinen, Korsman, and Mustonen (2013) made the connection very clear in their handbook for coaching floorball.

For the present article, the writers agreed to attempt to examine coaching leadership through the connection with broad pedagogical leadership. Thus, the focus would be on leadership focusing on developing both individuals and organizations in the same way as one would be doing participating coaching, or broad pedagogical leadership. As the first step, the writers discussed studies that they had themselves been conducting earlier and that seemed to fit the research setting. The studies should comprise either the sports or the school world, and have mentoring emphasizing leadership typical of participating coaching in the focus whether it was called coaching or pedagogical leadership. The writers found four studies that met the defined criteria: (a) interviews of 10 principals with a background of top coach (Pulkkinen, 2011); (b) writings of 12 adults working with young people (Pulkkinen \& Kanervio, 2014); (c) observations and teachers' group interviews in a unified comprehensive school with a focus on the principal's symbolic leadership (Lahtero, 2011); and (d) a survey on comprehensive school leadership team members' experiences on how strategic leadership is enacted in the work of leadership teams (Lahtero \& Kuusilehto-Awale, 2013).

As the second step, the writers examined four studies attempting to find shared characteristics locating as a common characteristic the concept of time. Time seemed to have a central position in both coaching and broad pedagogical leadership. It emphasizes respecting others, because time in one way or another regulates everybody's activities. One has to be able to manage time and proportion time and tasks with each other (Berg, 2006; Pulkkinen, 2011; Pulkkinen et al., 2013; Renton, 2009).

\section{Research Data}

As a result of the two-step dialogue between the writers, the following research data were located and analyzed for the present article. For the present article, the first set of data can be considered as the primary one, and the one leading the dialogue between the writers. As described below, the three other ones had a connection to either coaching or broad pedagogical leadership, and could thus be included in the examination. They can be regarded as secondary sets of data, and were used mainly either to confirm or to contradict the findings of the primary data.

1. Interviews of 10 principals with a background of top coach (Pulkkinen, 2011). Principals were required to have worked as comprehensive or general upper secondary school principals for at least three years. To be determined as top coaches, the principals were required to have been acting as team sport coaches either in the national top league or national team level for at least three years;

2. Writings of 12 adults working with young people. The data were originally to be included in the study 
by Pulkkinen and Kanervio (2014) and included a strong connection to coaching leadership but was preserved for other purposes during the research process. The writings were strongly connected to the world of the young, but included very different kinds of scopes. For the present article, the data offered information about how the young seem to perceive their world and how time is connected to the perceptions;

3. Observations and teachers' group interviews in a unified comprehensive school with a focus on the principal's symbolic leadership (Lahtero, 2011). Symbolic leadership, especially its connection to leading organizational culture, is one of the key developmental processes for the broad pedagogical leadership theory as identified by Alava et al. (2012). Altogether six teacher groups comprising 22 teachers were interviewed;

4. Survey on comprehensive school leadership team members' experiences on how strategic leadership is enacted in the work of leadership teams (Lahtero \& Kuusilehto-Awale, 2013). The data were collected using a questionnaire including 24 statements which the members of the leadership teams evaluated on a 5-point Likert-scale. The statements concerned how strategic leadership and its three areas-strategic planning, implementation of strategy, and evaluation of strategy — were enacted according to the leadership members in the work of their leadership teams. Strategic leadership, particularly leading strategic leadership, as a developmental process for individual and organizational learning, is one of the key developmental processes for the broad pedagogical leadership theory according to Alava et al. (2012). The survey was answered by 187 school leadership team members.

\section{Methods of Data Analysis}

Both the qualitative research data of three first studies and the quantitative one of the fourth study were analyzed using qualitative content analysis. It is a basic method of analysis which can be considered besides a single method also a loose theoretical framework which can be connected with various entities of thought. Most qualitative methods of analysis are based on content analysis (Tuomi \& Sarajärvi, 2002). Kyngäs and Vanhanen (1999) emphasized that with content analysis one can analyze documents like interviews in a systematic and objective manner. With content analysis, one can describe the research object in a condensed and general form.

\section{Results and Discussion}

Time appeared in many contexts and meanings. Time in its many forms was considered as one of the most essential aspects for coaching leadership. To get a good coaching feeling, a state that enables the right kind of presence demands a lot of work from coaches and principals. In that work, management of own time proved out to be the most important factor. One has to be honest to oneself and recognize the realities of life. One has to plan the use of time so that there is enough time for the most important task but also for rest and thinking. Haste is a bad explanation for lack of time, because coaches and principals are generally always busy. Haste must not obstruct the basic mission, helping the one being coached.

The work of neither coaches nor principals is decreasing, on the contrary, there are more and more tasks to do. To find time in the crossfire of increasing demands seems to become a bigger and bigger problem. On the other hand, the increasing disproportion has forced modern coaches and principals to include teams, team work, and shared leadership in their leadership, and this development can be considered positive and to advance coaching leadership as a whole. 


\section{Digital World Has Changed Interaction and Time Scope}

Digital world has changed our time concept in a radical manner. We need a new way of thinking that corresponds to the changed time concept so that we can adapt ourselves to the new world and its time concept (Pulkkinen \& Kanervio, 2014). Isotalo (2014) crystallized the changed time concept as follows:

Our time concept has changed although it was not us modern people who invented time. Through social media, it is possible to live the same time globally. Some young people interpret time so that they do not have sleep at all. One can always reach somebody virtually. One does not have to be reachable the whole time! (pp. 77-78)

The world of technology has not merely come to stay; it is developing and changing the every day in a significant manner. The young live the world of today. It is their world. Adults must learn to understand the world of the young so that they are able to take care of their responsibilities in bringing up children. There is no returning to the past, but one can and must take along from the past valuable things that work also in the new world. The new epoch where everything is available the whole time with their threats and opportunities must be greeted with respect, but one must not accept everything. There is no reason to panic. Time changes and people must change as the time changes.

\section{Time and Its Respect}

Time and its respect were mentioned in many interviews in several contexts and meanings. In the first set of research data, every interviewed principal with a background of top coach talked about it. Figure 1 presents the most central things which were described concerning time and its respect by the interviewees.

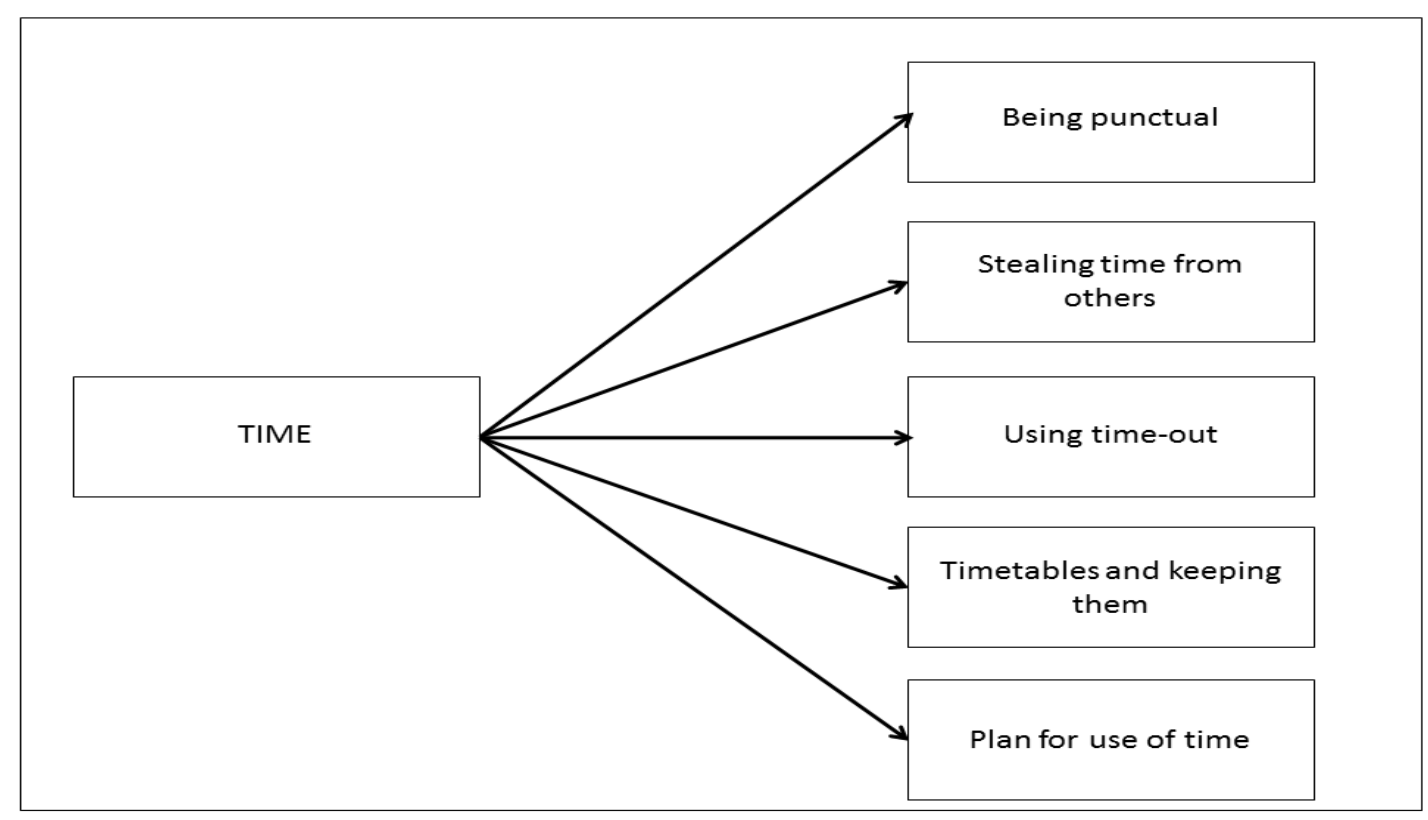

Figure 1. Factors concerning time and its respect (Pulkkinen, 2011, p. 134).

Time and respecting it were mentioned in connection to respecting all group members, which is the presupposition of successful group work. Respect meant commitment to keep the agreed timetable by group members. Respecting time is also respecting others, and time must be respected as a boundary, because it regulates everybody's work (Ahonen, 2004). This respect means among other things that one has to be on time. The following citation depicts respect for time in the sports world expressed by one of the interviewees. 
I believe that acting in sports has taught me to construct time, on the other hand, it has also taught determination. If something has been agreed on, then everybody sticks to it and does accordingly. Time must be respected. (Principal 1)

Respecting time in the sports world is based on the fact that there always is too little time, both in games and in practice. Very many team sports have their strict timetables, exercises are always results of many negotiations, and trips to away matches are scheduled so that the arrival to the venue is optimal, the same applies to home matches. Being on time is regarded sacred in the sports world. Respecting the everyday is part of following rules. Team sports are very effective educators of following rules. The rules of the game are the same for everybody, and breaking them immediately leads into punishment (I. Turkka \& V. Turkka, 2008). The same principle applies also to the school world. According to the interviewed coaching principals, there are a lot of people who stretch or steal time in the school world, both teachers and principals. People who steal time are not respected neither in sport teams or schools according to the interviewed principals. In fact, they are resented. The selfish actions of time thieves cause big problems in the school world as meetings and palavers are stretched (Ahonen, 2004).

Time-outs are a basic tactics used by coaches in the sports world. The interviewed coaching principals often have to take a time-out in order to ensure themselves time to think when something surprising takes place. It is not always sensible to give the answer right away, but take the time-out to reflect on the issue. The time-out can be shorter or longer depending on the situation. It is a good way to avoid impulsive decisions both in sports and school worlds (Ahonen, 2004). Speed is not always the most important thing; patience and a small break help clearing one's thoughts.

Timetables are used except in practice and games, also in the more general and long-term holistic planning of operations. Especially the period before the season includes a lot of deadlines whose keeping is a presupposition of a successful season. The school world includes similar deadlines which the coaching principals well seemed to have recognized when leading their schools. Below there is a citation on timetables by one of the interviewees.

I am clearly aware that I have ambition and that I rather do things so that they will succeed well. I do not always succeed perfectly, but I do not want to satisfy myself with mediocre or poor performance. It is important to be able to keep the timetables. It is something that I have because I have been an athlete but also because I have coached. (Principal 2)

Timetables do not always deal only with planning actions, but they have an important role also in the organization of work and in the evaluation of operational possibilities. Timetables are needed also when planning for having own time for mental and physical wellbeing (Ahonen, 2004). Principals' ever expanding workloads (Mäkelä, 2007) make timetables even more important. Time is a unique resource that must not be wasted in (Drucker, 2006).

The observations of the third research (Lahtero, 2011) revealed that the principal of the studied unified comprehensive school had a daily calendar beside the door to his office for everybody to see. According to the interviews of the subject groups, teachers considered the calendar to tell about the haste and diligence of the principal. In addition, all subject groups also regarded their principal to keep his timetables.

The principal keeps his calendar bookings well, and the timetables of meetings and everyday chores are also punctual. He does not forget his meetings. It is rare that he has to cancel a meeting. He is on time and punctually there. Somebody is always late, but the principal never. (Teacher 1)

Five subject groups considered that the way the principal of the unified comprehensive school kept his 
timetables reflected his respect for teachers.

As the principal is in information sessions and meetings on time, he expresses respect for teachers and appreciation of other people's time. He does not think it does not matter whether teachers have to wait. Also, the events themselves are important for the principal. (Teacher 2)

Despite the punctuality of the principal, all subject groups were of the opinion that teachers' meetings and information sessions are often prolonged because of teachers coming late to them.

Some teachers are not really aware that the academic quarter is not desirable in these kind of events. Teachers do not have discipline and meetings start late because of people going to get coffee. (Teacher 3)

The principal can, with his use of time, besides show respect to teachers, also express what tasks he regards important. According to the interviews of the subject groups, the principal of the unified comprehensive school prioritized student issues as the most important timetable issues.

They are more important to him than administrative issues. In the principal's use of time, student matters and unexpected problems go before many other errands. If one asks the principal for time in a student matter, he has the time although he would be busy. To him, the most important issues are acute situations where somebody is in physical danger. If there is an event taking place during the break, the principal will come there although he would have whatever meeting. (Teacher 4)

\section{Planning}

Planning is an essential part of use and management of time according to all the four sets of research data. In the first set of research data, coaching principals considered planning to be needed both in school and sports worlds. The Ministry of Education and Culture (2010) emphasized the compilation for school strategies in its quality card for leadership and management. Mintzberg (1994) defined strategies as planning systems with which one plans and controls decision-making and the future. Kirveskari (2003) summarized strategies always to deal with the future time and space. It is a model which connects the most important goals, principles, and tactics of an organization into a consistent entity.

Coaching principals who were the objects of the first set of research data the present article is based on are all coaching ball sports because of which they compared the sport season with the school year. They considered them to have an approximately similar length, and both were thought require careful preplanning. In their opinion, planning also is quite similar in both worlds because of the cyclicality of the planning. In both worlds, the planning of the yearly cycle is conducted on the basis of certain yearly repeating and similar cycles. This was seen to expand the understanding of planning and especially that of how everything is tied to time.

Strategic leadership is a general concept that refers at the same time to strategy as a whole and to its single elements: strategic planning, implementation of strategy, and evaluation of strategy (Lahtero \& Kuusilehto-Awale, 2013). Strategic planning is systematic collecting and use of data to determine long-term direction. It is a mixture of reflection, analysis of goals, and evaluation of priorities. It is ensuring the vitality and efficiency of an organization by mapping the direction of future operations. Strategic planning is, however, beneficial only when it is linked to implementation (Poister \& Streib, 2005).

The analysis of the fourth set of research data revealed that the school leadership team members in the comprehensive schools in Vantaa thought that there was a strong correlation between strategic planning, implementation, and its evaluation (Lahtero \& Kuusilehto-Awale, 2013). On the basis of the results, leadership 
team members were of the opinion that strategic planning was such an integral part of strategic leadership that separating it from the entity of strategic leadership would not be reasonable.

\section{Cyclicality}

Cyclicality of the use of time was examined through a strategic learning cycle based on organizational theory (Alava, 1999). It comprises four phases: (a) analysis; (b) visions; (c) commitment/interaction; and (d) concrete action. Including concept of time with the strategic learning cycle revealed cyclicality in the research results concerning the study on coaching principals. Both school and sports worlds apply in their cyclicality exactly the same pattern. The cycle of the school year is determined by the span of the school year, and the sport season correspondingly by the span of the sport season. This requires strong skills of situational leadership which has a key role in each cycle and in the leadership actions of the cycles. On the basis of the research data (Pulkkinen, 2011), cyclicality seems to include that kind of transfer which can be benefitted in the everyday management of both worlds.

The concretization of transfer can be depicted with the sphere of cyclical actions (Pulkkinen, 2011). It is similar to the strategic learning cycle by Alava (1999), but has been developed to serve especially coaching leadership. The sphere of cyclical actions has been presented in Figure 2.

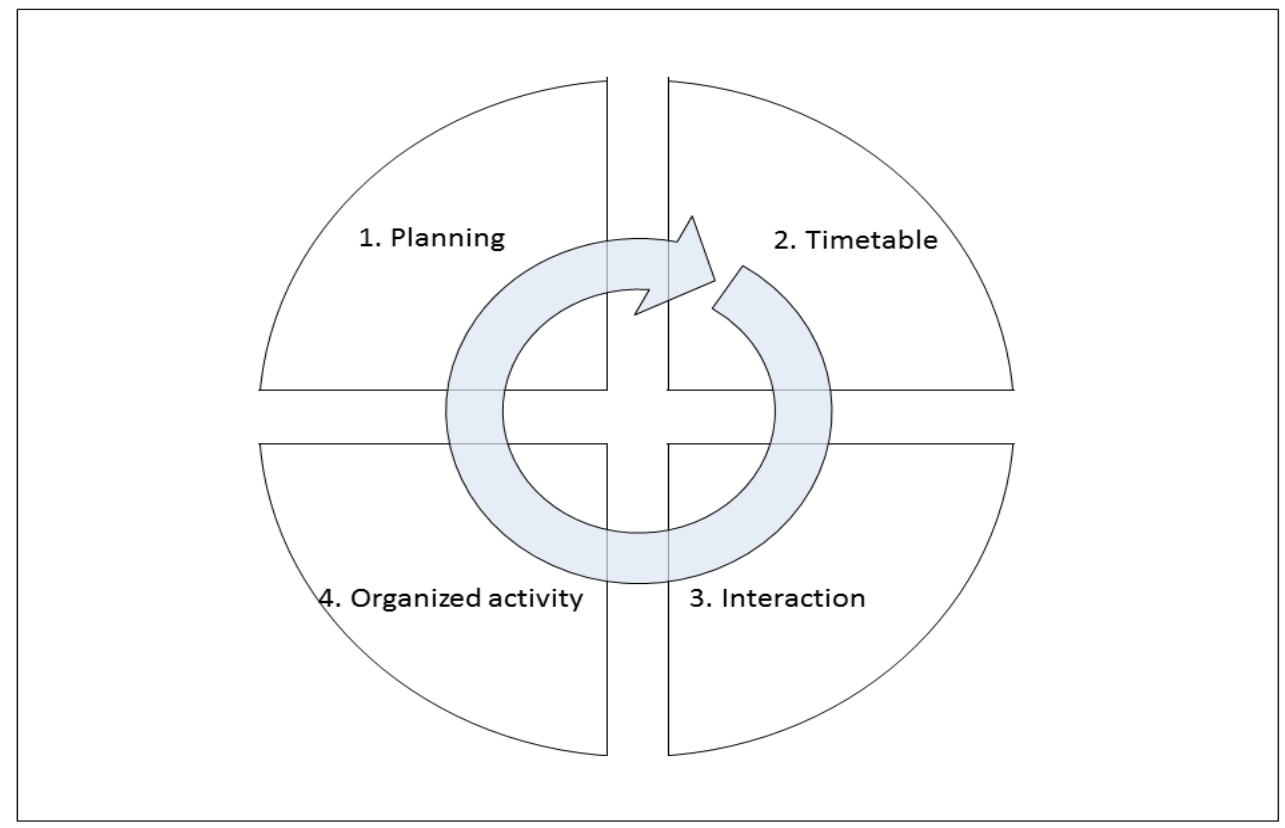

Figure 2. Sphere of cyclical actions (Pulkkinen, 2011, p. 165).

The sphere of cyclical actions consists of four phases. The starting point of the sphere is careful "planning". The old proverb "Well planned is half done" applies here (Silius, Tervakari, Kaikuvuo, Mäkinen, Vuosara, \& Puurtinen, 2007). The second phase is "timetable". It takes into consideration time and its requirements to implement the plan. It is followed by "interaction" with which the plan is "sold" to actors. Interaction and its management in all its forms can be considered as the presupposition of successful practice. After interaction, one has to have the appropriate "organizing" with which one enables the implementation of the plans in the right timetable. According to the cycle of the sphere, organized actions are again followed by planning which makes the sphere move and become a process that consistently develops itself. 
It comprises also in the sphere of cyclical actions, one of the four cycles, because without time and the timetables linked to it, the sphere of cyclical actions does not revolve. Each coach must be aware of time and its limits and respect it because in games and exercises, there normally is too little time. The time a coach spends together with the ones he/she coaches is limited, so it should always be used as well as possible. For example, many team sports are based on time; practice runs are always established as results of many negotiations. In addition, trips to away games are timed so that one comes to the venue at the optimal moment; the same principle applies to home games as well.

When one examines strategic leadership as a process, time in the progress of an organization's actions becomes in focus (Laine, 2010). As a concept, strategic leadership thus refers both to strategy as an entity and to its single elements (Rannisto, 2005). These elements are, according to Lahtero and Kuusilehto-Awale (2013), strategic planning, implementation of strategy, and evaluation of strategy. Huotari (2009) emphasized that strategic leadership shows up as cycles where planning, implementation, and evaluation follow and feed each other. Lahtero and Kuusilehto-Awale (2013) examined the experiences of school leadership team members in the City of Vantaa on how the leadership teams succeeded in the strategic leadership of their schools. The results indicated that leadership team members considered strategic leadership as moving cyclicality where strategic planning, implementation, and evaluation follow each other (see Figure 3). The scope on cyclicality does not seem to enable one to identify where strategic leadership starts and where it ends.

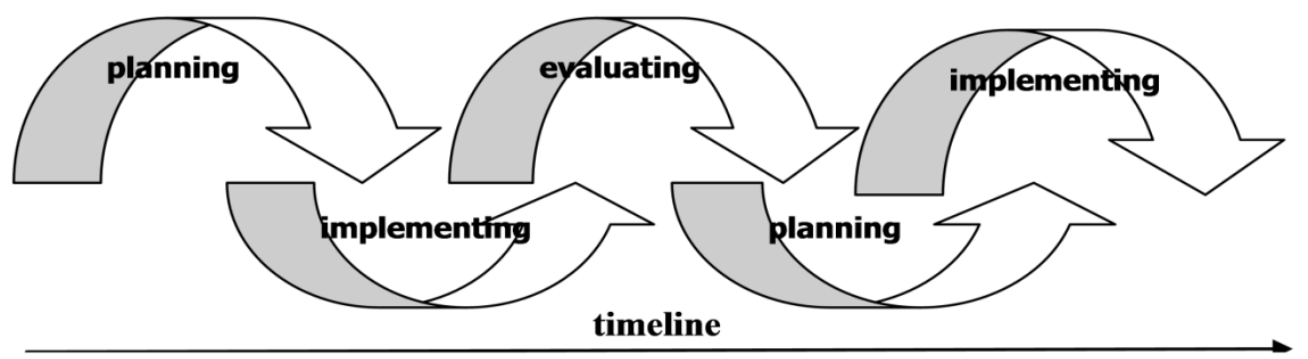

Figure 3. Strategic leadership as cyclicality of time.

The experiences leadership team members have on strategic leadership comprised the fourth set of research data of the present article. The experiences were studied by Lahtero and Kuusilehto-Awale (2013), who examined the experiences in relation to various background factors. According to their results, only the experience of the leadership team work of the answerer had a significant impact on the experience of how well strategic leadership had succeeded. Lahtero and Kuusilehto-Awale (2013) did not consider that strategic leadership is a separate entity which is not linked to other leadership work. From the perspective of time, they examined strategic leadership as an unbroken continuum which extends to history, present, and future. Also, the experience of success is determined by the timeline which extends to the past.

The significance of strategic leadership in coaching leadership is remarkable. Many studies support the perception. For example, according to Santasalo and Ahman's (2007) study on leadership teams, the leadership team members regarded strategic leadership as the second most important presupposition to successful leadership work. The most important factor was trust among leadership team members. In their study on the failures of chief executive officers (CEOs), Santasalo and Ahman (2007) noticed that lack of strategic leadership was the second most common reason for the failure of the CEOs. 


\section{Conclusion}

Coaching has changed Finnish leadership significantly. People have started to have courage to give up old practices. The shared leadership coaching leadership includes and the opportunities shared leadership offers have improved leadership. People have realized that times change and that they have to change correspondingly. It seems that coaching leadership and a broad view on pedagogical leadership have a lot in common. For example, for both learning, development, dialogue, and mentoring seem to be essential characteristics. It seemed valuable to compare the two approaches of leadership with each other. Concerning both approaches, time turned out to be an essential element in the enactment of the leadership style in practice.

Time has been a poorly guarded element of leadership. Time has not been respected and timetables have not been kept. People are late, timetables drag, and time is spent on ideas nobody believes in. Then, time has become an unsatisfactory companion. Many act as if an invisible mechanism had taken their discretion. They just satisfy themselves by saying that they always are in a hurry. That inhibits the rise of new ideas (Ahonen, 2004; Fried \& Hanson, 2011; Pulkkinen, 2011). New ideas require an allowing and tolerant atmosphere (Juuti, 2010). The data of this article indicate that successful coaching leadership demands enough time and presence from the leader. Time must be both respected and handled right.

There are several research findings concerning time in Finnish school leadership. Mäkelä (2007) noticed while studying the task areas of a Finnish comprehensive school principal that $31 \%$ of the task areas dealt with leading collaboration networks, $14 \%$ with pedagogical leadership, and $22 \%$ with staff management. Pulkkinen (2011) observed similar phenomena while studying coaching principals, and in addition, identified collaboration leadership to consist of four separate elements. To divide leadership in main categories from the point of view of time is interesting. If one divides the time a principal spends on leadership in main categories so that each of the main categories comprises several single tasks, the total sum of the time spent in the tasks will be $100 \%$. When one adds or takes away main categories or single tasks, one still has the same $100 \%$ for leadership. It is then no wonder that Juusenaho (2004) found lack of time to be a problem to principals. Especially the fact that principals' work has become more all-round and more many-sided has eaten time from what they consider important.

Unlike Mäkelä (2007) and Pulkkinen (2011), Lahtero and Kuusilehto-Awale (2013) did not consider leadership to consist of pieces that are separate of each other. They neither thought strategic leadership to be a separate leadership entity of its own. From the perspective of time, they examined leadership as a kind of unbroken continuum that extends from history, present, and future. Also, how one evaluates the success of actions is decided on the basis of the timeline stretching to the past of several years.

A principal can thus examine his/her planning or strategic leadership as a separate piece of leadership or as an unbroken continuum. In every case, he/she in the end is at the mercy of how other members of the school community interprets his/her use of time. The interpretative scope can be clearly seen in the study by Lahtero (2011). The principal who was studied in the research told in his interview that he considered planning the timeline and strategic leadership as the central task of the leadership team. He had defined the vision of the leadership team of his school in the following way:

The leadership team of the school is the dynamo of development, the pioneer of teaching, and the guiding star of the whole staff. Its task is to act as a work group of high expertise, and to support school development and pupils' and teachers' wellbeing. (Principal 3) 
The leadership team assembles for two hours at least once a month according to the timeline the principal has made. At least, this time the principal considered to spend mainly on planning and strategic leadership. Concerning the task of the leadership team, the interpretations of the subject groups differed clearly from that of the principal. All six subject groups considered that the most important tasks of the leadership team consisted of delegation, information flow, and shared leadership.

The principal has too much to do and being able to delegate tasks to leadership team members lightens his workload. Because of this leadership, team members answer for many things and have a lot of work. (Team member 1)

One can state that principals cannot decide on their own in what main category they locate their use of time. Through the interpretation process also, the working community decides on what the principal spends his time. According to Totro (2010), strategy can be examined as a social and interactive activity (strategy as practice). Significant are the situations where the activity takes place. Also, Laine (2010) considered strategic activity to take place as presence in the situation and not as conscientious strategic reflection. Things have been constructed as they are during history, and new meanings and structures are formed in that framework.

Time is perceived in several different ways, as acts in the everyday, as taking place according to the cyclical events, or as other acts or definitions that govern our lives (Ahonen, 2004). Time is everywhere and it is always present. Time can be handled whether it is limited or limitless, if it can be given the right status and position in the leadership process. Time has to be seen as a companion that one has time for, and one has to abandon pointless haste (Peltola, 2011). How time is perceived can be influenced strongly by the superior whether he/she is a coaching principal or whoever, and whether he/she can deal with time and people in the right way. Both must be respected and appreciated.

\section{References}

Ahonen, H. (2004). Kuka komentaa kelloasi? (Who is managing your time?). Helsinki: Kirjapaja.

Alava, J. (1999). Organizational change in the union of professional engineers in Finland and the union of professional social workers in Finland. Lexington, K.Y.: University on Kentucky.

Alava, J., Halttunen, L., \& Risku, M. (2012). Changing school management: Status review-May 2012. Helsinki: Finnish National Board of Education.

Berg, M. E. (2006). Coaching: A hjelpeledereogmedarbeideretil a lykkes (Coaching: To help managers and employees to succeed). Oslo: Universitetsforlaget.

Carlsson, M., \& Forssell, C. (2008). Esimies ja coaching: Oivaltava coaching johtamisen työkaluna (Leadership and coaching: Insightful coaching as a management tool). Helsinki: Tietosanoma.

Drucker, P. (2006). The effective executive. New York, N.Y.: Harper Collins Publishers.

Eskola, J., \& Suoranta, J. (2003). Johdatus laadulliseen tutkimukseen (Introduction to qualitative research). Tampere: Vastapaino.

Fried, J., \& Hanson, D.H. (2011). Rework. New York, N.Y.: Crown Publishing Group.

Harmaja, T., \& Hellbom, K. (2007). Coaching-toimialan kehittyminen ja kasvu (The development and growth of the coaching industry). In M. Räsänen (Ed.), Coaching ja johtajuus: Valmentava ote esimiestyössä (Coaching and leadership: Coaching touch in managerial work) (pp. 213-229). Helsinki: Edita.

Heikinaro-Johansson, P. (2003). Johdatus liikuntadidaktiikkaan (Introduction to PE didactics). In P. Heikinaro-Johansson, T. Huovinen, \& L. Kytökorpi (Eds.), Näkökulmia liikuntapedagogiikkaan (Perspectives to pedagogy in sports) (pp. 101-129). Helsinki: WSOY.

Huotari, P. (2009). Strateginen osaamisen johtaminen kuntien sosiaali-Ja terveystoimessa: Neljän kunnan sosiaali-ja terveystoimen esimiesten käsityksiä strategisesta osaamisen johtamisesta (Strategic knowledge and capacity management in municipal social and healthcare sector: Perceptions of social and healthcare sector managers of managing and leading strategic knowledge and competence). Tampere: Tampereen yliopistopaino Oy_Juvenes Print.

Isotalo, K. (2014). Rehtorin huuto! (Principal's cry!). In P. Hamarus, P. Kanervio, L. Landen, \& S. Pulkkinen (Eds.), Huuto! (Cry!). Jyväskylä: PS-kustannus. 
Juusenaho, R. (2004). Peruskoulun rehtoreiden johtamisen eroja: Sukupuolinen näkökulma (Elementary school principals' leadership differences: Gender perspective). Jyväskylä Studies in Education, Psychology and Social Research, 249.

Juuti, P. (2010). Työhyvinvoinnin strategia—Mitä sillä tarkoitetaan? (Well-being strategy—What is it?). In M. Suutarinen, \& P. L. Vesterinen (Eds.), Työhyvinvoinnin johtaminen (Leading well-being in work) (pp. 45-55). Helsinki: Otava.

Kantola, H. (1989). Valmennuksen suunnittelu ja ohjelmointi (The training design and planning). In H. Kantola (Ed.), Suomalainen valmennusoppi 2: Harjoittelu (Finnish coaching 2: Training) (pp. 133-150). Helsinki: Suomen Olympiakomitea.

Kirveskari, T. (2003). Visiot oppilaitoksen johtamisessa: Tulevaisuuden tahtotilaa muodostamassa (Visions in educational management: Forming the goals of future). Tampere: Acta Universitatis Tamperensis 933.

Kuusilehto-Awale, L., \& Pulkkinen, S. (2013, September 20). On the relationship between caring and coaching leadership. Paper presented at The ENIRDELM Conference, Portoroz, Slovenia.

Kyngäs, H., \& Vanhanen, L. (1999). Sisällön analyysi (Content analysis). Hoitotiede, 1, 3-12.

Lahtero, T. J. (2011). Yhtenäiskoulun johtamiskulttuuri-Symboli-tulkinnallinen näkökulma (Leadership culture ín a comprehesive school—Symbolic-interpretative perspective). Jyväskylä: Jyväskylä University Printing House.

Lahtero, T. J., \& Kuusilehto-Awale, L. (2013). Realisation of strategic leadership in leadership teams' work as experienced by the leadership team members of basic education schools. School Leadership \& Management, 3(5), 457-472.

Laine, P. (2010). Toimijuus strategiakäytännöissä: diskurssi-Ja käytäntöteoreettisia avauksia (Agency in strategy praxis: Discursion and system theoretical openings) (Series A-1). Turun kauppakorkeakoulu/Turku School of Economics.

Mäkelä, A. (2007). Mitä rehtorit todella tekevät: Etnografinen tapaustutkimus johtamisesta ja rehtorin tehtävistä peruskoulussa (What principals really do: An ethnographic case study on leadership and principals' tasks in comprehensive education school). Jyväskylä: Jyväskylä University Printing House.

Ministry of Education and Culture. (2010). Perusopetuksen laatukriteerit (Quality criteria in comprehensive eucation). Helsinki: Yliopistopaino.

Mintzberg, H. (1994). The rise and fall of strategic planning. New York, N.Y.: Prentice-Hall.

Peltola, H. (2011). Yhtenä: Kun minästä kasvaa me (As one: When one grows to us). Helsinki: WSOYpro.

Poister, T. H., \& Streib, G. (2005). Elements of strategic planning and management in municipal government: Status after two decades. Public Administration Review, 65(1), 45-56.

Pulkkinen S., \& Kanervio P. (2014). Nuorten elämismaailma (The world of young). In P. Hamarus, P. Kanervio, L. Landen, \& S. Pulkkinen (Eds.), Huuto! (Cry!). Jyväskylä: PS-kustannus.

Pulkkinen, S. (2011). Valmentajataustan merkitys rehtorin työssä (Significance of coaching background in principal's work). Jyväskylä: Jyväskylä University Printing House.

Pulkkinen, S., Korsman, J., \& Mustonen, J. (2013). Valmentaminen salibandyssä (Coaching in floorball). Jyväskylä: PS-kustannus.

Rannisto, P. (2005). Kunnan strateginen johtaminen: Tutkimus seinänaapurikuntien strategiaprosessien ominaispiirteistä ja kunnanjohtajista strategisina johtajina (Municipal's strategic management: Research concenring the strategy process characteristics in neighboring municipalities and the municipal directors as strategic leaders). Tampere: Acta Universitatis Tamperensis 1072 .

Renton, J. (2009). Coaching and mentoring: What they are and how to make the most of them. London: Profile Books Ltd..

Santasalo, L., \& Ahman, H. (2007). Toimitusjohtajien ja johtoryhmän jäsenten coaching (Coaching of the managers and the members of the executive team). In M. Räsänen (Ed.), Coaching ja johtajuus: Valmentava ote esimiestyössä (Coaching and leadership: Coaching touch in managerial work) (pp. 57-65). Helsinki: Edita.

Silius, K., Tervakari, A. M., Kaikuvuo, I., Mäkinen, M., Vuosara, V., \& Puurtinen, H. G. (2007). Hyvin suunniteltu on puoliksi tehty-Tapaustutkimus.Invlididliiton verkkopalvelusta (Wellplanned is half done-Case study of the website of the association of people with physical disabilities). In C. H. Nygard, H. Eskola, J. Hyttinen, \& M. Savinainen (Eds.), Näkökulmia hyvinvointiteknologiaan (Perspectives on welfare technology) (pp. 47-65). Tampere: Tampereen Yliopistopaino.

Totro, T. (2010). Matkalla vallan strategiasta vallattomaan (On the way from the strategy of power to powerless). In M. Tensing, \& T. Totro (Eds.), Vallaton strategia-Puheenvuoroja strategisesta toisinymmärtämisestä (Powerless strategy—Speeches of understanding strategy otherwise) (pp. 15-53). Vihanti: Rannikon Laatupaino Oy.

Tuomi, J., \& Sarajärvi, A. (2002). Laadullinen tutkimus ja sisällön analyysi (Qualitative research and content analysis). Helsinki: Tammi.

Turkka, I., \& Turkka, V. (2008). Icehearts: Joukkue kasvun tukena (Icehearts: The club for supporting growth). Jyväskylä: PS-kustannus. 